\title{
THE ROLE OF KIAI HISYAM ZUHDI IN DEVELOPING ISLAMIC BOARDING SCHOOLS ON THE CHARACTER OF SANTRI
}

\author{
Miswan Ramdani ${ }^{1}$, Mahlil Nurul Ihsan ${ }^{2}$ \\ STAI Sukabumi Bandung, Indonesia \\ Pascasarjana Universitas Islam Negeri Sunan Gunung Djati Bandung, Indonesia \\ rmiswan142@gmail.com, mahlilnurulihsan05@gmail.com,
}

Received: 20-06-2021

Revised: 09-09-2021

Accepted: 29-10-2021

\begin{abstract}
The purpose of this study is to discuss the role of Kiai Hisyam in developing the AtTaujeuh Al-Isalmy Islamic boarding school, Randegan Village, Kebasen District, Banyumas Regency. This research method uses qualitative field research to describe the role of kyai in developing pesantren with data collection techniques in the form of interviews, observation and documentation. The results in this study indicate that Kiai Hisyam Zuhdi has a role in the field of education at the At Taujieh Al-Islamy Islamic Boarding School, Banyumas Regency as follows: as the leader of the Islamic boarding school as a driver of the religious program of students, teaching of religious knowledge, builder of worship for students, forming the Islamic character of students, supervisors of religious students and those in charge of pesantren who have an important role in developing quality pesantren.
\end{abstract}

Keywords: The Role of Kiai, Development of Islamic Boarding Schools, Character Education

\begin{abstract}
Abstrak
Tujuan penelitian ini membahas peran kiai Hisyam dalam mengembangkan pondok pesantren AtTaujeuh Al-Isalmy Desa Randegan Kecamatan Kebasen Kabupaten Banyumas. Metode penelitian ini menggunakan penelitian kualitatif lapangan untuk mendeskripsikan peran kyai di dalam mengembangkan pesantren dengan teknik pengumpulan data berupa wawancara, observasi dan dokumentasi. Hasil kajian dalam penelitian ini menunjukan babwa Kiai Hisyam Zubdi memiliki peran dalam bidang pendidikan di Pondok Pesantren At Taujieh Al-Islamy Kabupaten Banyumas sebagai berikut :sebagai pimpinan pesantren sebagai penggerak program keagamaan santri, pengajar ilmu keagamaan, pembina beribadah santri, pembentuk karakter Islami santri, pengawas keberagamaan santri dan penanggung jawab pesantren yang memiliki peran penting dalam mengembangkan pesantren yang bermutu.
\end{abstract}

Kata Kunci :Peran Kiai dan Perkembangan Pesantren, Pendidikan Karakter

\section{INTRODUCTION}

Islamic boarding school History has shown enormous progress in Indonesia and produced many national figures from boarding. These figures have fought in the history of the Indonesian nation, both as heroes, scientists, national leaders and so on. ${ }^{1}$ According to

\footnotetext{
${ }^{1}$ Maksum, M. Refleksi Pesantren : Otokritik dan Prospektif. Jakarta: Ciputat Institute, (2007), 10
} 
Soetomo, the view of Islamic boarding school is to see Islamic boarding school as a cultural investment force, namely, Islamic boarding school as fertile land and also a golden opportunity to imagine the nature and character of the nation. In its history, Islamic boarding school introduced them to a civilization that was very rich in cultural achievements in the fields of religion, literature, art, and spirituality. ${ }^{2}$ Islamic boarding schools have a major role in educating students from various walks of life regardless of social, economic or ethnic status.

The previous research related to the role of kyai in Islamic boarding schools is as follows: the role of the kyai has an important role in socio-political life in Indonesia in instilling religious values in the life of the nation ${ }^{3}$, the role of the kyai in shaping the social behavior of a clean and healthy society makes a harmonious life. ${ }^{4}$, the role of the kyai's leadership style in developing Islamic boarding school which is directed at shaping the diversity of students ${ }^{5}$, the role of the kyai in the Islamic boarding school in shaping the character of the santri ${ }^{6}$, the kyai's role in forming a harmonious Islamic boarding school environment in the practice of the religious diversity of the santri in the Islamic boarding school $^{7}$, the role of the kyai in society in building the religious values of the communitythe kyai in society in building religious values ${ }^{8}$, the role of. Kyai in providing the charisma of traditional boarding schools ${ }^{9}$, the role of kyai in improving the spiritual intelligence of students in the daily life of students ${ }^{10}$, the role of kyai in the socio-religious community ${ }^{11}$ and the role of kyai in creating communication and interaction of religious students in the community. student ${ }^{12}$. While this study focuses on discussing the role of kyai in developing Islamic boarding school at the At Taujieh Al Islamy Islamic boarding school, Randegan Village, Kebasen District, Banyumas Regency to study the important role of kyai in developing Islamic boarding school so that the direction of Islamic boarding school development is directed towards the benefit of students.

The role of Islamic boarding school is no less important when viewed in terms of improving the quality of human resources. In the Islamic boarding school transition, there are five main elements that become the basic elements of the Islamic boarding school ${ }^{13}$, namely:

\footnotetext{
${ }^{2}$ Baso, A. Pesantren St 2A. Jakarta: Pustaka Afid,(2013), 45

${ }^{3}$ Faridl, M.. Peran Sosial Politik Kyai di Indonesia.Jurnal Sosioteknologi,6(11) (2007), 238-243.

${ }^{4}$ Wahyudin, U., \& Setiaman, A.. Karakteristik dan Peran Kyai Dalam Sosialisasi Perilaku Hidup Bersih dan Sehat (PHBS) di Islamic boarding school.Jurnal Manajemen Komunikasi,3(2) (2019), 122-130.

${ }^{5}$ Noor, M. Gaya Kepemimpinan Kyai.Jurnal Kependidikan,7(1) (2019), 141-156.

${ }^{6}$ Kurniati, M., Surur, M., \& Rasyidi, AH Peran Kepemimpinan Kyai Dalam Mendidik Dan Membentuk Karakter Santri Yang Siap Mengabdi Kepada Masyarakat. Al-Bayan: Jurnal Ilmu al-Qur'an dan Hadist,2(2) (2019), 194-203.

7 Arifin, Z. Peran Kyai dalam Membina Keharmonisan Keluarga Pondok Islamic boarding school. $A S A$ : Jurnal Kajian Hukum Keluarga Islam,3(1) (2021).

${ }^{8}$ Husein, MB, \& Roziq, A. Peranan Kyai Sebagai Pemimpin Lokal Dalam Pelaksanaan Pembangunan Desa Larangan Luar Kabupaten Pamekasan.Reformasi,11(2) (2021), 120-129.

9 Musaropah, U. Kharisma Kyai Dalam Organisasi Pendidikan Islamic boarding school Tradisional.Ulumuddin: Jurnal Ilmu-ilmu Keislaman,8(2) (2018), 141-155.

${ }^{10}$ Baihaqi, A.. Peran Kyai Untuk Meningkatkan Spiritual Quotient.Dakwatuna: Jurnal Dakwah dan Komunikasi Islam,3(2)(2017), 1-27.

${ }^{11}$ Mustafidah, A.Peran tokoh agama dalam kehidupan sosial keagamaan: studi peran Kyai Abdul Hakim di Desa Lajo Lor Kecamatan Singgahan Kabupaten Tuban(Doctoral dissertation, UIN Sunan Ampel Surabaya (2018).

12 Pertiwi, AK. Analisis Interaksi Simbolik Kyai dan Santri Dalam Perspektif Kepemimpinan Berbasis Nilai Dan Etika.JMSP (Jurnal Manajemen dan Supervisi Pendidikan),2(3) (2018), 185-191.

${ }^{13}$ Dhofier, Z. Tradisi Pesantren ; Studi tentang Pandangan Kiai. Jakarta: LP3ES, (1990), 2
} 
first, the cottage which is a student dormitory building where students live together to study. Second, the mosque besides being a place of worship is used as an education center. Third, santri which is the designation for students who study in Islamic boarding schools. Fourth, kiai who become caregivers as well as teachers in the Islamic boarding school. Fifth, classical Islamic books which are sources of knowledge in Islamic boarding schools.

This study focuses more on the character of the Islamic boarding school. In the Banyumas area, precisely in Leler Hamlet, Randegan Village, Kebasen District, there is a large Islamic study center, namely Islamic boarding school At Taujieh Al Islamy. The Islamic boarding school founded by Kiai Muhammad Zuhdi in 1914 AD was originally given the name Tarbiyah Nahwiyah which is familiarly called Pondok Leler is just a mosque that is used as a place to study religion. The response from the local community who was negative about religious matters made the initiative to build a boarding school building so that it could be used as a center for Islamic religion and make it a medium for Islamic da'wah in the Randegan area and its surroundings. KH Muhammad Zuhdi died in 1937 at the age of 50 years. According to Mbah Hasyim Suyuthi (sister-in-law of KH Muhammad Zuhdi), when KH

Muhammad Zuhdi died his eldest son was circumcised (sepit). His age ranges from 67 years. He felt very sad about the death of his father and always shed tears every time after visiting his father's grave. Especially if he saw the cottage building which was getting quieter and quieter. Tarbiyah Nahwiyah (Pondok Leler) experienced a period of vacuum in 1937-1944 $\mathrm{AD}$ after KH Muhammad Zuhdi died and only started activities again after KH Muhammad Zuhdi's eldest son, Hisham Zuhdi, returned from the cottage. So that the explanation of the role of the kyai in the development of the Islamic boarding school is more clearly discussed in the findings and discussion.

\section{METHOD}

In order to obtain scientifically research results, a method that is appropriate to the object under study is required. The method used in this research is the historical research method. The historical research method is an investigation of a problem by applying the solution from a historical perspective. According to Gilbert J. Garraghan, that historical research method is a systematic set of rules and principles for collecting historical sources effectively, evaluating them critically, and proposing a synthesis of the results achieved in written form. ${ }^{14}$

Heuristics is a technique of finding and collecting historical source data both orally and in writing. ${ }^{15}$ The historical source data can be obtained from: 1) Documentary materials Can be in the form of autobiographies, personal letters, notes or diaries, memoirs, newspapers, government documents or official archives, romance stories or novels. 2) Manuscripts or Handscrift Apart from archives, researchers also have to track down manuscript materials such as Javanese, Balinese, Bugis, Malay scripts, and so on. Manuscripts or manuscripts (handschrift) that can be used as sources of intellectual history by using a philological approach. 3) Oral sources Oral history sources are usually focused on key informants, namely historical actors (people who are directly or indirectly involved in an

\footnotetext{
14 Abdurahman, D. Metodologi Penelitian Sejarah Islam. Yogyakarta: Penerbit Ombak (2011), 103

15 Priyadi, S. Metode Penelitian Sejarah. Yogyakarta: Pustaka Pelajar. Rifyana, (2011), 28
} 
event) and historical witnesses (people who are witnesses or spectators of an event). 4) Artifacts can be in the form of buildings (obelisks, dams, temples, tombs, mosques, churches, houses and so on) or historical objects (axes, house tools, war tools and so on). Heuristics is a technique of finding and collecting historical source data both orally and in writing. Sources of primary data from this study is the family of Kiai Hisham Zuhdi and secondary data sources are all data and supporting information related to figure Kiai Hisham Zuhdi and Islamic boarding school At Taujieh Al Islamy such as books, social media and articles

\section{RESULTS AND DISCUSSION RESULTS}

The role of Kyai in Islamic boarding school This is very important in running the education wheel of the Islamic boarding school, because the Kiai is the first person to implement policies, regulations and as a driver of the Islamic boarding school program. Based on the results of interviews with Kiai Hisyam Zuhdi that the role of Kiai in the At-Taujieh AlIslamy Islamic boarding school in Banyumas Regency is as follows: The

\section{Leader Of The Islamic Boarding School As A Driver Of The Religious Program Of The Santri}

Kiai Hisyam Zuhdi has a role as the leader of the At-Taujeh Al-Islamy Islamic boarding school in Banyumas Regency with a democratic leadership style make this Islamic boarding school full of religious values so that these values are applied in everyday life. The leadership role of Kiai Hisyam Zuhdi made his policy so that students always carry out religious programs actively by participating in various religious recitation and learning programs for students in Islamic boarding schools. The At-Taujeh Al-Islamy Islamic Boarding School in Banyumas Regency is able to run because of Kiai Hisyam Zuhdi who always continues to foster Islamic boarding school through santri religious programs so that students can carry out their obligations to study in Islamic boarding school well while practicing religious knowledge in the form of carrying out daily prayers. - day of students at the boarding school. As the role of the kyai as a leader has high charisma in moving the religious program of the santri, so that the santri have obedience in carrying out the daily worship of the santri in the Islamic boarding school.

Kiai Hisyam Zuhdi's leadership in Islamic boarding school is very influential on the development of Islamic boarding schools, therefore the leadership of Kyai is very influential in moving the wheels of the Islamic boarding school religious program which makes students able to pursue religious knowledge and carry out religious observances in the lives of students at this boarding school. Kyai's leadership can also influence the policies of the Islamic boarding school where the policy of this Islamic boarding school can affect the Islamic boarding school programs that make students obedient in carrying out worship. Kyai's policies also have a role to play in improving values and boarding schools that make students disciplined, diligent in worship and skilled in social life, which makes students useful for religion, society, nation and state. Kyai's policies are always related to programs that are legalized in Islamic boarding schools so that all students can take part in religious programs properly to instill and practice the values of Islamic teachings applied in the daily lives of students in Islamic boarding school. The Kyai's policies at the Salafi Islamic boarding school 
are that students are included in attending prayers on time, students are required to carry out the Yellow Book recitation programs and also participate in religious activities that are applied in the daily lives of students at the Islamic boarding school. Therefore, with the Kyai's policies, it can be directed in shaping the obedience of students to worship in daily life at the Islamic boarding school which causes the santri to be able to move the religious programs that make the santri obedient in carrying out daily worship in the Islamic boarding school.

\section{Cultivator of religious values}

Kiai Hisyam Zuhdi as the leader of the Islamic Boarding School has a role to instill religious values in the Islamic boarding school program in the form of religious programs, recitation programs, lecture programs and also worship programs that are applied in the daily life of santri in Islamic boarding school so that all santri can instill values. religious values that are implemented in the daily life of santri in Islamic boarding school. The cultivation of religious values is really very influential on the development of Islamic boarding schools because Islamic boarding schools are designed by Kyai in order to foster faith as well as knowledge and noble character attitudes that are applied in daily life supported by Islamic boarding schools programs so that they are relaxed and active in carry out the routine of worship and recite the Koran every day in the Islamic boarding school well.

Instilling values can be applied in the form of religious lectures aimed at making students have an understanding in practicing religious values such as the value of sincerity, the value of brotherhood, the value of cleanliness, and values that uphold noble character in the daily life of students at the boarding school which shows the existence of The religiosity of the santri in practicing the teachings of Islam is applied in the daily life of the santri in the Islamic boarding school. Instilling religious values can also be applied in the teaching of the yellow book and religious books which have great benefits in instilling the values of diversity in students in Islamic boarding schools so that students can understand the concept of worship and implement attitudes in everyday life based on values. religion that is beneficial to the lives of students and the surrounding community. The cultivation of religious values is indeed true to be applied in everyday life because as the leader of the Kyai Islamic Boarding School has a great responsibility in instilling religious values that are supported by other Ustadz in the form of worship, especially religious values can be applied in the form of recitation of the Book. and others that greatly influence the formation of religious understanding of students in practicing the teachings of Islam in the daily lives of students in boarding schools.

The cultivation of religious values can also be applied in the habituation of students who are taught and familiarized by the Kyai to the students of Allah who is always active in participating in religious programs, especially in carrying out habituation of prayer, the habit of reading the discussion of cleanliness and the habituation of habituation that has religious values that affect the formation of religious values. the religious attitude of the students in the daily life of the students at this boarding school and the values that are instilled are the Salafi values so that they always respect teachers and also respect others and love knowledge and love good deeds as well as many more values that are instilled in everyday life. So that these religious values grow in the souls of students so that students have strong faith and can also 
carry out worship diligently and actively in understanding religious knowledge and also practicing the diversity of students in Islamic boarding schools.

\section{Teachers of religious sciences}

Every day students are taught by Kyai to always follow the recitation of the Yellow Book as a form of Kyai's teaching about religious sciences so that students can have a strong understanding and a great aqidah basis regarding the religious sciences which are the life of students in Islamic boarding school so that the blessings of life are certainly guided by strong religious knowledge so that later they can carry out worship actively. The teaching of religious knowledge of students is taught every day so that students always actively participate in routine activities in carrying out book recitation activities as well as religious knowledge to increase students' awareness of carrying out diversity in the daily life of students in Islamic boarding schools to form an attitude of religious tolerance because students' religious knowledge broad and also makes these Salafi students have the awareness to always preach and always carry out religious activities in the daily lives of students who show the religious value and obedience of students to worship at this boarding school.

The religious science lessons of santri are followed by all santri in the Islamic boarding school and are also followed by the community because this Salafi Islamic boarding school is open to seeking knowledge for those who want the pleasure of Allah and also the blessing of life, that is why Kyai always teaches religious knowledge to santri so that they have good knowledge and manners. also educate students so that they always practice the religious knowledge received from the Kyai to the santri to be used as a religious program later in the Islamic boarding school. The teachings of religious sciences that are applied in the daily lives of students at Islamic boarding schools are teaching the science of fiqh, Quranic Hadith, history, morals, jurisprudence and Nahwu Shorof science and all knowledge related to the Quran such as Tafsir and other sciences that affect development. knowledge of students in boarding schools. Basically, this teaching aims to form the obedience and awareness of students in carrying out worship with full responsibility, students regularly in discipline in carrying out daily worship in Islamic boarding schools.

The method used by Kiai Hisyam Zuhdi in teaching the religious knowledge of students at the Al-Taujieh Al-Islamy Islamic boarding school in Banyumas Regency is as follows: 1) The Sorongan and bandongan methods are methods applied in understanding religious knowledge in religious books by discussing letter by letter, word by word. , sheet by sheet until the religious book of the Islamic boarding school is finished, then proceed to the next religious book of the santri. Then the students also listened to Kiai Hisyam Zuhdi's explanation regarding the teaching of the book, after that the students reread individually so that it aimed to improve the students' reading skills. 2) The madrasah diniyah method is this method used by Kiai Hisyam Zuhdi in teaching in a classical form with a large number of students, then each student is given class stages based on the religious mastery of students, so that the knowledge taught by Kiai Hisyam Zuhdi can be well received. 4) The method of habituation of students was applied by Kiai Hisyam Zuhdi in getting used to disciplining students in practicing the values of religious knowledge in the form of obedience to mandatory worship and sunnah as a form of the process of forming the Islamic character of students at the Al-Taujieh Al-Islamy Islamic Boarding School, Banyumas Regency. 4) The 
lecture method is often used by Kiai Hisyam Zuhdi in explaining religious knowledge through weekly events so that students have good religious knowledge by delivering the lecture method. Kiai Hisyam Zuhdi's lecture method was applied in the form of religious lectures for students and also for the surrounding community in fostering the religion of students and the community. 6) The Exemplary method of Kiai Hisyam Zuhdi is applied so that students can always practice the values of science, religion and morals in the daily lives of students in forming students' religious observance at the Al-Taujieh Al-Islamy Islamic Boarding School, Banyumas Regency. 7) The method of advice is used to provide enlightenment of religious knowledge that is implanted in the souls of students so that awareness grows in studying religion and also practices religious values in the daily lives of students at the Al-Taujieh AlIslamy Islamic Boarding School, Banyumas Regency.

\section{Santri Worship}

Guidance for Coaching for worship, cannot be separated from the guidance of Islamic boarding school leaders who have the responsibility to foster santri worship which is the main task of the kyai in fostering the diversity of santri in this Islamic boarding school so that they love and get used to the obedience of worship that is applied in the daily lives of students who have many benefits so that life is blessed and also always this Islamic boarding school. The role of the Kyai in this Islamic boarding school is as a worshiper and has the main goal in shaping the attitude of the students based on the values of the One Godhead and also with Kak amal pious who is a santri who respects the honor given. The guidance for the worship of students is also directed at forming an obedient attitude in carrying out the daily worship of students in Islamic boarding schools which can also increase the responsibility of students in carrying out worship. .

This guidance for santri worship has implications for the formation of santri worship obedience in the daily life of santri, because this santri worship guidance is applied in the daily life of santri which makes students obedient in carrying out worship. The guidance for the worship of students is an important aspect of the role of the kiyai in the Islamic boarding school, because all of these santri religious programs are formed and fostered to realize aattitude religiousof balanced and noble students in the daily lives of students at the Islamic boarding school as well as to cultivate the values of the obedient attitude of the students. in the boarding school which includes all students in this boarding school. The guidance that is applied can be in the form of guidance, direction and training so that students are truly embedded in the religious values of students in Islamic boarding school.

\section{Shaping the Islamic Character of the santri}

The role of the kyai in this Islamic boarding school is to form the Islamic character of the santri which is applied in everyday life so that the santri have the obedience of worship and also the character with Islamic nuances which makes the jewelery of the santri in shaping the character in living the daily life of the santri in this Islamic boarding school. Of course, character education in this Islamic boarding school requires exemplary efforts from the Kyai and also from the teachers to always instill Islamic personality values. The formation of this Islamic character can be applied through habituation of training and teaching as an inculcation of religious values and also with everything that can improve Islamic character, of course, is the environment of rules and discipline of students so that students can always carry out 
worship obedience and carry out worship obligations and also in practicing the knowledge received. Students who are applied in everyday life.

The formation of this Islamic character can be formed into a patient attitude, an obedient attitude and a sincere attitude in charity which shows the gratitude of the Santri in carrying out the religious teachings of the santri in the Islamic boarding school. Character formation is of course accustomed to in everyday life through strengthening rules that make students able to have religious power and are also beneficial to society and the people. The process of forming this Islamic character begins with the habit of worshiping so that students form an obedient attitude to worship and also the attitude of the hands applied in the daily life of students at the Islamic boarding school. The formation of the Islamic character of the santri is part of the role of the Kiai so that the life of the santri in the Islamic boarding school is continuously formed and directed to form the Islamic character of the santri which is applied in the daily life of the santri so that the santri have strong faith, a solid character and good deeds. which is useful, so that the role of the kyai in the Islamic boarding school makes the life of the santri thick with the formation of Islamic character which is applied in the daily life of the santri in this Islamic boarding school.

\section{The supervisor of santri religiosity}

The role of Kiai Hisyam Zuhdi in Islamic boarding school in developing Islamic boarding school cannot be separated from the supervision of santri religiosity which aims to always supervise the activities of students at Al-Taujieh Al-Islamy Islamic boarding school so that students always practice the religious values of students in the Islamic boarding school. In developing the Islamic boarding school, Kiai Hisyam Zuhdi always supervises his students to carry out regular recitations and also supervises the students to carry out the daily worship of the students in the Islamic boarding school so that the students are really supervised by the busyness of the Al-Taujieh Al-Islamy Islamic boarding school in carrying out their activities. obedience to worship of students such as Kiai Hisyam Zuhdi supervises students in carrying out congregational prayers, supervises in fostering religious knowledge through supervision of reciting the yellow book and also oversees the habit of worshiping students at the Al-Taujeih Al-Islamy Islamic boarding school. Kiai Hisyam Zuhdi's supervision of his students has an important role, so that all religious programs and the Koran and even the habituation of students can be continuously directed in shaping theattitudes religiousof students at the AlTaujieh Al-Islamy Islamic boarding school which makes students obedient in carrying out worship in everyday life. students at this boarding school.

The supervision of Kiai Hisyam Zuhdi is a form of efforts to develop Islamic boarding school to maintain compulsory worship and the sunnah of students, as well as overseeing the implementation of the yellow book recitation and supervising the habituation of santri worship which is the main program of Islamic boarding school which is constantly being improved in the daily lives of students at Al. -Taujieh Al-Islamy Islamic boarding school. The supervision of Kiai Hisyam Zuhdi in the development of Islamic boarding schools is directed at forming an attitude of worship and love for the religious knowledge of students which are the religious values of students in this boarding school, because the goal of developing Islamic boarding school is to improve the quality of students' worship and also the 
quality of religious knowledge that is applied in their lives. students who can run well through the discipline of students and the supervision of Kiai Hisyam Zuhdi

\section{The Person In Charge Of The Islamic Boarding School}

The role of Kiai Hisyam Zuhdi in the Al-Taujieh Al-Islamy Islamic boarding school, Banyumas Regency is as the person in charge of the Islamic boarding school, because with the attitude of responsibility Kiai Hisyam Zuhdi makes the implementation of the development of the Al-Taujieh Al-Islamy Islamic boarding school is developing well in terms of increasing the religious knowledge of students in the process of reciting books and religious guidance and having the responsibility to instill and familiarize students to worship in the Islamic boarding school. The attitude of responsibility of Kiai Hisyam Zuhdi has an important role so that all religious programs can run well, and can increase so that students are obedient in carrying out the daily worship of students at the Islamic boarding school. This responsibility is a very noble task that is owned by Kiai Hisyam Zuhdi in developing Islamic boarding school, so that students are more obedient in worship and are also more diligent in participating in the religious programs of students at the Islamic boarding school. The role of Kiai Hisyam Zuhdi's attitude of responsibility is seen in terms of his good teaching, gentle religious guidance and supervising the religious programs of santri with full responsibility, so that Kiai Hisyam Zuhdi's role is a model for Kiau's leadership in developing a better Islamic boarding school.

The role of Kiai Hisyam Zuhdi can run well in developing the Al-Taujieh Al-Islamy Islamic Boarding School in Banyumas Regency which is supported by the cooperation of the Islamic boarding school teachers who make the development of the Islamic boarding school run rapidly. Therefore, the role of Kiai Hisyam Zuhdi in Islamic boarding school can be carried out properly if all components of the Islamic boarding school support each other in implementing the Islamic boarding school program which are equally applied in a balanced manner so that the development of Islamic boarding school can be continuously improved on the values of santri worship, the value of knowledge and The moral values applied in the daily life of students at the Al-Taujeih Al-Islamy Islamic Boarding School in Banyumas Regency as a form of Islamic boarding school development is a sign that religious education is continuously being improved through various roles of Kiai in Islamic boarding school and provides enormous benefits to the formation of obedience. worshiping students and also the formation of the Islamic character of students in the daily lives of students at the Al-Taujieh Al-Islamy Islamic Boarding School, Banyumas Regency.

\section{DISCUSSION}

\section{The Role Of Kiai Leadership In Driving The Santri Religious Program In Educating The Character Of The Santri}

Kiai Hisyam Zuhdi has an important role in developing pesantren in the aspect of character education for students, as is his role as a leader who has an important role to lead and mobilize the religious program of students at the At Taujieh Al Islamy Islamic boarding school. According to the theory that the role of the kyai in the pesantren has a role as a role 
model for his students who become role models for the students in thinking and behaving ${ }^{16}$, then with the leadership of the kyai in the pesantren, it has an important role in shaping the character education of the santri in the pesantren so that the example and leadership of the kyai continues. applied in everyday life in fostering the character of students in Islamic boarding schools. Likewise, the leadership role of the kyai can be successful in shaping the character of students when using charismatic style leadership so that all students can imitate ${ }^{17}$ and shape the daily character of santri in pesantren which is directed to form independent, responsible, social, diligent and disciplined characters The leadership role of the kiai becomes the identity of the pesantren leadership style to be directed in fostering the diversity of santri in the daily life of santri in boarding school. ${ }^{18}$

Kiai Hisyam Zuhdi's leadership also has an important role in developing the innovative behavior of students so that students have productive lives that are beneficial to the surrounding community. ${ }^{19}$ The key word in educating the character of the santri is that it is useful and can spread goodness and benefits to many people as character education that is continuously formed on the religious character of the santri in the pesantren. The leadership of the santri also plays a very important role in developing the quality of the pesantren, because the pesantren will look very good in terms of the performance of the kiai's leadership in the pesantren ${ }^{20}$ as seen from the development of pesantren in Indonesia. community and has an important role in improving the quality of pesantren education. ${ }^{21}$ The life of the pesantren is also dynamic because of the developments due to the demands of the times so that in addition to studying religion, students are also required to go to school so that students have a balanced knowledge in everyday life. ${ }^{22}$ Pesantren will develop well, because the role of the kiai is open so that the development of pesantren as a form of the kiai's leadership role is very important in carrying out the wheels of religious education in pesantren.

\section{The Role Of The Kiai As A Teacher And Inculcating The Religious Knowledge Of Students}

The role of the kiai in Islamic boarding schools has an important role in instilling religious values that are applied in everyday life, as the role of the kiai is multifunctional as a character planter through teaching and as a character builder for students through habituation of Islamic characters in the daily life of students in pesantren. ${ }^{23}$ The position of the kiai in this pesantren has great virtue in teaching and instilling religious values that are directed at the formation of Islamic santri character that reflects the noble identity of the santri. ${ }^{24}$ The position of the kiai is very respectable, because the role of the kiai has a principal role in

16 Pertiwi, AK. Analysis of the Symbolic Interaction of Kyai and Santri in Values and Ethics-Based Leadership Perspective. JMSP (Journal of Educational Management and Supervision), 2(3) (2018), 185-191.

${ }_{17}$ Noor, M. Kyai Leadership Style. Journal of Education, 7(1) (2019), 141-156.

18 Safii, I. (2020). Kyai's Leadership Model in Forming Independent Santri in Era 4.0. Al-Mada: Journal of Religion, Social, and Culture, 3(2), 218-240.

19 Pramitha, D. Kyai leadership in modern Islamic boarding schools: Organizational development, team building, and innovative behavior. Journal of Educational Management Accountability, 8(2) (2020), 147-154.

20 Shodiq, M. Kyai's Leadership in Improving the Quality of Islamic Boarding School Education. el-hikmah (2011).

21 Afandi, R. The Effectiveness of Islamic Boarding School Transformational Leadership for Quality Improvement of Islamic Educational Institutions. Journal of Education, 1(1) (2013), 99-122.

22 Ulum, N. Kyai's Leadership in Changing Islamic Boarding Schools. JOURNAL OF Aswaja Education and Studies, 6(2) (2020)

23 Alwi, BM. Islamic boarding schools: characteristics, development, and education system. Lantern Pendidikan: Journal of Tarbiyah and Teacher Training, 16(2) (2013), 205-219

24 Muhakamurrohman, A. (2014). Pesantren: Santri, kiai, and traditions. IBD A: Journal of Islamic and Cultural Studies, 12(2), 109-118. 
instilling the religious values of the santri and the community in the pesantren so that the inculcation of these religious values lasts the life of the kiai. ${ }^{25}$ The role of the kiai as a teacher and inculcating the religious knowledge of students has a very large contribution in internalizing the religious values of students which are applied in daily life as well as the religious teaching of students in this pesantren as an effort to improve the quality and quality of pesantren education in instilling religious values. in pesantren. ${ }^{26}$ The success of the kiai's role in developing the pesantren, there is an aspect of the character of the santri. This is influenced by the kiai's upbringing which makes the santri truly embedded in the religious values of the santri in the pesantren so that the santri can practice religious teachings in the daily life of the santri.

The planting of religious knowledge of students is applied every day so that students have high religious awareness in carrying out worship obligations which are directed at the formation of the Islamic character ofstudents religious. The kyai implements various learning methods such as the lecture method, demonstration method, exemplary method, question and answer method, advice method and many more. ${ }^{27}$ The planting of religious knowledge of students takes place continuously so that students have high religious awareness in carrying out religious orders and are able to stay away from all prohibitions. The cultivation of religious knowledge given by the kiai is very useful in instilling the character of the santri in the pesantren, so that every day cannot be separated from the recitation and coaching that takes place in the daily life of the santri in the pesantren.

\section{The Role Of The Kiai As A Builder Of Worship (Religion) For Students}

The role of kiai Hisyam Zuhdi in pesantren has a very important role in fostering the worship of santri, because with this religious guidance it is directed at shaping the Islamic character of santri in pesantren. Like many studies that explain the role of kiai in fostering worship, it is very important with the application of disciplined, independent, responsible, honest and patient characters that make students obedient in religion as a result of strong religious guidance in shaping the Islamic character of students in pesantren. ${ }^{28}$ The form of religious guidance applied by the kiai goes hand in hand with the habit of worshiping students which is applied in the daily lives of students at the pesantren which makes students diligent and active in worship, because religious guidance is carried out continuously so that students form Islamic characters in life. in pesantren which is influenced by theatmosphere and environment of the pesantren religious. ${ }^{29}$

The guidance for the worship of santri is a form of the effort to play the role of the kiai in shaping the Islamic character of the santri in the pesantren, because without this guidance, the good character of the santri will not be realized. Therefore, it takes a long process in fostering the Islamic character of the santri applied in the pesantren which is strengthened by the kiai's rules in disciplining the santri in worship and in carrying out the duties and obligations of the santri in the pesantren. Fostering the worship of santri is also the joint responsibility of the kiai and asatidz in fostering the attitude and worship of santir in

${ }^{25}$ Usman, IM. Pesantren as an Islamic educational institution. Journal of Al Hikmah, 14(1) (2013), 101-119.

${ }^{26}$ Fahham, AM. Islamic boarding school education: parenting patterns, character building, and child protection. Publica Institute Jakarta (2020).

${ }^{27}$ Nofiaturrahmah, F. Character education methods in Islamic boarding schools. Journal of Islamic Religious Education, 11(2) (2014), 2001-216

28 Badiusman, B. Fostering the Discipline of Worshiping Santri at the Iqra'barung-Barung Islamic Boarding School, Balantai, Koto Xi Tarusan District, Pesisir Selatan Regency. Ruhama: Islamic Education Journal, 1(1) (2018).

${ }^{29}$ Firman, M. Character Development of Santri through Exemplary Kyai in Islamic Boarding Schools: A Qualitative Descriptive Study at As Syafi'iyah Islamic Boarding School Sukabumi in 2012 (Doctoral dissertation, Indonesian Education University) (2013). 
daily life at the pesantren which is continuously improved so that the formation of the character of the santri is truly formed in the daily life of the santri in the pesantren. The purpose of fostering daily student worship is the formation of the disciplined character of students in carrying out their daily obligations and duties at the pesantren. ${ }^{30}$

\section{The Role of The Kiai As The Shaper Of The Islamic Character Of The Santri}

The role of the kiai is very important in shaping the Islamic character of the santri in the pesantren, as many studies link the role of the kiai with his efforts to shape the Islamic character of the santri which is applied in the daily life of the santri in the pesantren. ${ }^{31}$ The character of the santri in the pesantren is formed due to the influence of the kiai who is very charismatic who makes every santri imitate the example of the kyai, so that the image of the pesantren will be seen from the role of the kiai as well as the driving force of the pesantren culture in shaping the character of the santri. ${ }^{32}$ The Islamic character of santri in pesantren is part of pesantren education so that santri in carrying out daily life activities reflect religious values in the form of good character, so that Islamic character education continues to be formed by kyai so that students have a noble personality in living the daily lives of students. at the boarding school. The Islamic character of the santri is an inseparable part of the education of the pesantren, because the kiai every day always provides an example, habituation and upholding the rules of the pesantren in order to form the Islamic character of the santri in the pesantren. ${ }^{33}$

The formation of the character of these students becomes a very important religious program in Islamic boarding schools such as obedient students in praying, discipline in worship, being independent in carrying out work, being helpful to others and having high integrity. The role of the kiai in the pesantren in shaping the character of the santri has a very important position, because the kiai is as a religious teacher, builder and shaper of the Islamic character of the santri which is applied in the daily life of the santri in the pesantren. All of these santri character education continue to be fostered until the santri character is embedded in the soul of the santri so that the santri have a high Islamic character.

\section{The Role of Kiai As Supervisor And Person In Charge Of Students}

The role of the kiai in the pesantren has a great responsibility in overseeing the daily life of the santri, so the rules of the pesantren are formed so that the santri have a good personality and character in living their religious life in the pesantren. ${ }^{34}$ The kiai's supervision in shaping the Islamic character of the santri in this pesantren is applied consistently, because character building requires consistent teaching, coaching and supervision so that the santri are truly directed at theattitude religiousof the santri in living the daily lives of the santri in the pesantren. Supervision of santri in this pesantren is part of the kiai's role in nurturing santri, so that the supervision of this santri cannot be separated from the kiai's upbringing so that students always multiply worship, recite the Koran and get used to living practicing the teachings of Islam which affect the formation of the Islamic character of students in the pesantren. ${ }^{35}$ The role of the kiai in supervising the character of the santri is carried out

30 Anam, C., \& Suharningsih, S. Model of Santri Discipline Development (Case Study of Darul Fiqhi Islamic Boarding School, Lamongan Regency). Moral and Citizenship Studies, 2(2) (2014), 469-483

${ }^{31}$ Fitriyah, L. The role of the kiai in shaping the character of the santri at the Yasmida Ambarawa Islamic boarding school, Pringsewu district (Doctoral dissertation, UIN Raden Intan Lampung) (2019).

32 Arifin, Z.. Islamic Boarding School Culture in Building Student Character. Al Qodiri: Journal of Education, Social and Religion, 6(1) (2014), 1-22

33 Nashori, F.. Strength of student character. Millab: Journal of Religious Studies, 11(1) (2011), 203-219

34 Rokhmawati, FN. Monitoring system for the activities of the students of the Roudlotul Qur'an Lamongan Islamic Boarding School (Doctoral dissertation, UIN Sunan Ampel Surabaya) (2018).

35 Dasir, AD, \& Munawiroh, M. Parenting Patterns for Darul Muttaqin Islamic Boarding School Parung Bogor. Penamas, 33(1) (2020), 153-174. 
consistently and fully with patience so that the santri can direct their character in practicing Islamic teachings in the daily life of the santri.

This supervision of students is a form of coaching so that students can really carry out the religious program of students at the boarding school and form the responsibility of students in carrying out the santri worship program at the pesantren. Therefore, the supervision of this santri must be continuously applied so that the character of the santri can be formed in practicing religious values in the form of the Islamic character of the santri in the pesantren. Supervision of these students becomes very important, because with the supervision of the kiai, they can evaluate the students properly so that their character is further improved.

\section{CONCLUSION}

The role of Kiai Hisyam Zuhdi in the development of Pondok At Taujieh Al Islamy In the field of education, Kiai Hisyam Zuhdi applies the salaf system that emphasizes $\mathrm{Al}$ Ulum Ad Diniyah. As for several methods that were previously only the sorogan and bandongan methods, Kiai Hisyam Zuhdi applied the Madrasah Diniyah method. According to Kiai Hisyam Zuhdi, with the classical level of ability, this method is very effective for teaching a large number of students. The madrasah diniyah method used by Kiai Hisyam Zuhdi is learning that is limited to a class system according to the level of ability of the students. The advantage of using this madrasah diniyah method is that large numbers of students begin to be accommodated one by one. Kiai can measure the ability of students to learn individually. In addition to applying the madrasah diniyah method, Kiai Hisyam Zuhdi uses a unique way to convey knowledge, namely by demonstrating what he is explaining. So, in his recitation Kiai Hisyam Zuhdi not only monotonously reads and explains as kiai do in general, but demonstrates all scientific material so that students do not feel bored and quickly understand what he is explaining. The role of Kiai Hisyam Zuhdi in the development of the Al-Taujieh Al-Islamy Islamic boarding school in Banyumas Regency is as follows: as the leader of the Islamic boarding school as a driver of the religious program of students, teaching religious knowledge, builder of worship for students, forming the Islamic character of students, supervisors of religious students and the person in charge of boarding schools who have a role in important in developing quality Islamic boarding school.

\section{REFERENCES}

Abdurahman, D. Metodologi Penelitian Sejarah Islam. Yogyakarta: Penerbit Ombak, 2011, 103

Afandi, R. The Effectiveness of Islamic Boarding School Transformational Leadership for Quality Improvement of Islamic Educational Institutions. Journal of Education, 1(1) 2013, 99-122.

Alwi, BM. Islamic boarding schools: characteristics, development, and education system. Lantern Pendidikan: Journal of Tarbiyah and Teacher Training, 16(2) 2013, 205-219

Anam, C., \& Suharningsih, S. Model of Santri Discipline Development (Case Study of Darul Fiqhi Islamic Boarding School, Lamongan Regency). Moral and Citizenship Studies, 2(2) 2014, 469-483

Arifin, Z. Islamic Boarding School Culture in Building Student Character. Al Qodiri: Journal of Education, Social and Religion, 6(1) 2014, 1-22 
Arifin, Z. Peran Kyai dalam Membina Keharmonisan Keluarga Pondok Islamic boarding school. AS A: Jurnal Kajian Hukum Keluarga Islam,3(1), 2021.

Badiusman, B. Fostering the Discipline of Worshiping Santri at the Iqra'barung-Barung Islamic Boarding School, Balantai, Koto Xi Tarusan District, Pesisir Selatan Regency. Rubama: Islamic Education Journal, 1(1), 2018.

Baihaqi, A.. Peran Kyai Untuk Meningkatkan Spiritual Quotient.Dakwatuna: Jurnal Dakwah dan Komunikasi Islam,3(2) 2017, 1-27.

Baso, A. Pesantren. Jakarta: Pustaka Afid, 2013.

Dasir, AD, \& Munawiroh, M. Parenting Patterns for Darul Muttaqin Islamic Boarding School Parung Bogor. Penamas, 33(1) 2019, 153-174.

Dhofier, Z. Tradisi Pesantren; Studi tentang Pandangan Kiai. Jakarta: LP3ES, 1990.

Fahham, AM. Islamic boarding school education: parenting patterns, character building, and child protection. Publica Institute Jakarta, 2002.

Faridl, M.. Peran Sosial Politik Kyai di Indonesia.Jurnal Sosioteknologi,6(11) 2007, 238-243.

Firman, M. Character Development of Santri through Exemplary Kyai in Islamic Boarding Schools: A Qualitative Descriptive Study at As Syafi'iyah Islamic Boarding School Sukabumi in 2012 (Doctoral dissertation, Indonesian Education University), 2013.

Fitriyah, L.the role of the kiai in shaping the character of the santri at the Yasmida Ambarawa Islamic boarding school, Pringsewn district (Doctoral dissertation, UIN Raden Intan Lampung), 2019.

Husein, MB, \& Roziq, A. Peranan Kyai Sebagai Pemimpin Lokal Dalam Pelaksanaan Pembangunan Desa Larangan Luar Kabupaten Pamekasan.Reformasi,11(2) 2021, 120 129.

Kurniati, M., Surur, M., \& Rasyidi, AH Peran Kepemimpinan Kyai Dalam Mendidik Dan Membentuk Karakter Santri Yang Siap Mengabdi Kepada Masyarakat.Al-Bayan: Jurnal Ilmu al-Qur'an dan Hadist,2(2), 2019, 194-203.

Maksum, M. Refleksi Pesantren: Otokritik dan Prospektif. Jakarta: Ciputat Institute, 2007.

Muhakamurrohman, A. Pesantren: Santri, kiai, and traditions. IBD A: Journal of

aropah, U. Kharisma Kyai Dalam Organisasi Pendidikan Islamic boarding school Tradisional.Ulumuddin: Jurnal Ilmu-ilmu Keislaman,8(2) 2018, 141-155.

Mustafidah, A.Peran tokoh agama dalam kehidupan sosial keagamaan: studi peran Kyai Abdul Hakim di Desa Lajo Lor Kecamatan Singgahan Kabupaten Tuban(Doctoral dissertation, UIN Sunan Ampel Surabaya, 2018.

Nashori, F. Strength of student character. Millah: Journal of Religious Studies, 11(1) 2011, 203 219

Nofiaturrahmah, F. Character education methods in Islamic boarding schools. Journal of Islamic Religious Education, $11(2)$ 2014, 2001-216

Noor, M. Kyai Leadership Style. Journal of Education, 7(1) 2019, 141-156.

Pertiwi, AK. Analysis of the Symbolic Interaction of Kyai and Santri in Values and EthicsBased Leadership Perspective. JMSP (Journal of Educational Management and Supervision), 2(3) 2018, 185-191.

Pramitha, D. Kyai leadership in modern Islamic boarding schools: Organizational development, team building, and innovative behavior. Journal of Educational Management Accountability, 8(2) 2020, 147-154.

Priyadi, S. Metode Penelitian Sejarah. Yogyakarta: Pustaka Pelajar. Rifyana, (2011), 28

Rokhmawati, FN. Monitoring system for the activities of the students of the Roudlotul Qur'an Lamongan Islamic Boarding School (Doctoral dissertation, UIN Sunan Ampel Surabaya), 2018. 
Safii, I. Kyai's Leadership Model in Forming Independent Santri in Era 4.0. Al-Mada: Journal of Religion, Social, and Culture, 3(2) 2020, 218-240.

Shodiq, M. Kyai's Leadership in Improving the Quality of Islamic Boarding School Education. el-hikmah, 2011

Ulum, N. Kyai's Leadership in Changing Islamic Boarding Schools. JOURNAL OF Aswaja Education and Studies, 6(2) 2020.

Usman, IM. Pesantren as an Islamic educational institution. Journal of Al Hikmah, 14(1) 2013, 101-119.

Wahyudin, U., \& Setiaman, A.. Karakteristik dan Peran Kyai Dalam Sosialisasi Perilaku Hidup Bersih dan Sehat (PHBS) di Islamic boarding school.Jurnal Manajemen Komunikasi,3(2) 2019, 122-130. 